\title{
Hubungan Persepsi Dengan Sikap Petani Sayur Hidroponik Terhadap Sistem Pemasaran Online di Kota Jambi
}

\author{
* Rogayah dan WiwinAlawiyah \\ Program Studi Agribisnis Fakultas Pertanian Universitas Batanghari \\ Jl.Slamet Riyadi,Broni Jambi. 36122. Telp +62741-60103 \\ *e-mail korespondensi : gaya.rogayah1959@gmail.com
}

\begin{abstract}
This study was conducted to determine the relationship between perceptions and attitudes of hydroponic farmers toward to the online marketing system. There were 17 Hydroponic farmers, especially mustard as population and further all become the sample (census technic sampling). The research was conducted in Jambi City as there were many farmers who seek hydroponic vegetable cultivation methods had not fully marketed their products with online applications yet.Fisher's test was used to analyze the relationship between perception and the attitude of farmers toward to the online marketing system. The results showed that there was 12 farmers $(70,58 \%$ ) that showed a bad perception toward to online marketing system and showed low category of attitude. Furthermore, as many as 2 farmers $(11.76 \%)$ showed a good perception toward to the online marketing system and had a low attitude. While having a good perception with a high attitude as many as 3 people (17.64\%), which means these three farmers supported the online market. Fisher's Test result give $P=0.015$, which means it rejected alternative hypothesis, so it was stated that there was no relationship between perception and the attitude of hydroponic vegetable farmers toward to the online marketing system.
\end{abstract}

Keywords: Perception, Attitude, Online marketing

\begin{abstract}
Abstrak. Penelitian ini dilakukan untuk mengetahui hubungan persepsi dengan sikap petani sayur hidroponik terhadap sistem pemasaran online. Petani sayur hidroponik khususnya petani sayur pakcoi yang menjadi populasi sebanyak 17 orang dan seluruh petani ini diambil secara sensus sebagai sampel. Penelitian dilakukan di Kota Jambi dengan alasan di Kota jambi petani yang mengusahakan cara budidaya tanaman sayur secara hidroponik belum seluruhnya memasarkan hasil dengan aplikasi online. Untuk melihat hubungan antara persepsi dengan sikap petani sayur terhadap sistem pemasaran online digunakan uji Fisher. Hasil penelitian menunjukkan dari 17 sampel mempunyai persepsi kurang baik terhadap sistem pemasaran online yaitu 12 orang atau $70,58 \%$ dan sikap rendah. Selanjutnya sebanyak 2 orang 11,76\% mempunyai persepsi baik terhadap sistem pemasaran online dan bersikap rendah. Sedangkan berpersepsi baik dengan sikap tinggi sebanyak 3 orang atau 17,64 \% yang berarti ketiga orang ini mendukung adanya pasar online. Setelah dilakukan perhitungan menggunakan Uji Fisher hasilnya $\mathrm{P}=0,015$ yang artinya terima H0 dan tolak Ha sehingga dinyatakan tidak terdapat hubungan antara persepsi dengan sikap petani sayur hidroponik terhadap sistem pemasaran online.
\end{abstract}

Kata kunci: Persepsi, Sikap, Sistem pemasaran online

\section{PENDAHULUAN}

Indonesia merupakan Negara agraris yang memiliki potensi besar dalam sektor pertanian,luasnya lahan yang tersedia dan tingkat kesuburan lahan yang tinggi membuka peluang untuk kegiatan usaha pertanian sehingga pertanian memiliki arti yang penting sebagai penyedia lapangan pekerjaan bagi penduduk Negara Indonesia dan selain itu sebagai penyedia pangan dan hortikultura.

Seiring dengan pertumbuhan penduduk yang semakin meningkat maka kebutuhan terhadap lahan untuk pemukiman juga semakin banyak sehingga lahan yang digunakan untuk usaha pertanian dirasakan semakin berkurang,selain itu jumlah lahan yang tersedia semakin meningkat harganya Jika kita ingin memiliki hal ini menyebabkan kegiatan budidaya pertanian mengalami kendala karena mereka yang ingin melakukan kegiatan pertanian harus memiliki modal yang besar.Hal ini menyebabkanberkurangnya produksi pertanian, khususnya pangan untuk memenuhi kebutuhan masyarakat.

Jika kita membandingkan antara jumlah penduduk yang semakin meningkat dengan produksi bahan pangan yang dihasilkan dari sektor pertanian tentunya tidak sebanding,hal ini mendorong sektor pertanian untuk mengatasi kendala tersebut dengan meningkatkan pertanian lahan sempit.

Ketersediaan lahan di Provinsi Jambi juga mengalami penurunan terutama untuk tanaman hortikultura hal ini dikarenakan banyaknya masyarakat yang lebih memilih membudidayakan tanaman perkebunan seperti karet,kelapa sawit,kopi, pinang dan kelapa dalam hal inilah yang menyebabkan semakin berkurangnya ketersediaan lahan untuk tanaman hortikultura karena tanaman perkebunan itu membutuhkan areal yang luas untuk diusahakan karena jarak tanam antar tanaman itu sendiri cukup jauh yaitu nimimal 5 (lima) meter berbeda dengan tanaman hortikultura yang dapat diusahakan pada areal yang sempit bahkan tidak membutuhkan tanah seperti hidroponik. (Dispertan Kota Jambi.2018)

Hidroponik atau istilah asingnya Hyroponics adalah istilah yang digunakan untuk menjelaskan beberapa cara bercocok tanam tampa menggunakan tanah sebagai tempat media tanam. Prinsip dasar cara budidaya hidroponik ini sebenarnya sudah dikenal beberapa abad yang lalu,namun Negara asalnya secara pasti tidak diketahui.Tetapi pada 
tahun 1669 di Negara Inggris hidroponik telah diuji coba di sebuah laboratorium demikian pula pada tahun 1850 di Negara Sakura Jepang,namun pada saat itu bercocok tanam cara hidroponik hanya terbatas untuk penelitian... (Anindita $\mathrm{R}, 2004)$

Dari hasil uji coba di laboratoriun pada tahun 1994 yang dilakukan oleh kelompok Investigasi dari Laboratoriun Teknologi Tanaman Universitas San Jose California untuk mengetahui kandungan Vitamin dan mineral yang ada dalam tanaman yang dihasilkan dari cara budidaya hidroponik dan membandingkannya dengan tanaman yang dihasilkan dengan cara budidaya konversional,hasil uji coba ini menunjukkan bahwa tanaman yang dihasilkan dengan cara budidaya hidroponik memiliki vitamin dan mineral yang secara signifikan lebih tinggi dan sangat bermanfaat bagi kesehatan manusia jika dibandingkan dengan cara budidaya konvensional dan organic,namun tanaman yang dihasilkan dari cara budidaya hidroponik memiliki nilai jual yang jauh lebih tinggi bila dibandingkan tanaman yang dihasilkan dengan cara konvesional seperti misalnya sayuran selada hasil hidroponik dihargai dengan nilai Rp 35.000 per Kg dan menempati pasar modern (Supermaket) sedangkan selada yang dihasilkan dari cara konvensional dipasarkan dengan nilai Rp 5000,- sampai Rp 7000,-per Kg dan menempati pasar tradisional,jika kita membandingkan antara segmen pasar yang ditempati oleh kedua komoniti ini sangan jauh berbeda dan demikian pula pendapatan yang diperoleh petani produsen. (Anindita R,2004). Di Kota Jambi Pasar yang menyediakan sayuran hidroponik masih tergolong sedikit,hal ini terlihat dari tidak semua pusat perbelanjaan menyediakan sayuran hidroponik kondisi ini desebabkan karna adanya kelangkaan sayuran hidroponik dikarenakan masih sedikitnya petani yang mengusahakan dengan cara hidroponik hal ini dasebabkan masyarakat jambi masih memilih sayuran yang dihasilkan dengan cara konvesional karena harganya jauh lebih murah,oleh karena itu untuk meningkatkan jumlah penjualan sayuran hidroponik petani harus melakukan cara pemasaran yang berbeda dengan yang biasa dilakukan,salah satu cara yang dapat dilakukan petani adalah melalui pemasaran online, banyak keuntungan yang dapat diperoleh petani diantaranya petani bisa memperoleh konsumen yang tidak terbatas pada daerah sendiri saja atau jangkauan pemasaran lebih jauh, waktu memasarkan tidak terbatas mulai dari pagi hari sampai larut malam, hemat biaya karena tidak perlu lagi menyewa tempat untuk meletakkan dagangannya, transaksi lebih mudah dilakukan, jumlah sayuran yang terjual lebih banyak sehingga petani akan memperoleh pendapatan yang tinggi Kotler. P (2007). Berdasarkan uraian diatas maka penulis ingin mengetahui apakah terdapat hubungan persepsi dengan sikap petani hidroponik terhadap sistem pemasaran online di Kota Jambi.

\section{METODE PENELITIAN}

Penelitian ini dilaksanakan pada masa pandemic Covid 19,sehingga usaha yang dilakukan untuk memenuhi kebutuhan dan menghindari kerumunan maka cara online merupakan salah satu cara yang tepat.Kajian penelitian dipokuskan pada persepsi petani hidroponik terhadap sistem pemasaran online di Kota Jambi adapun data yang dikumpulkan dalam penelitian ini pengetahuan,pemahaman dan sikap petani hidroponik.terhadap sistem pemasaran online.

Jenis data berdasarkan waktu yang digunakan yaitu data Cross Section.Data yang digunakan adalah data kualitatif dengan skala pengukuran nominal yang menggunakan pengukuran secara non parametric. Data yang dikumpulkan dalam penelitian ini meliputi data primer dan data sekunder. Data primer dikumpulkan melalui wawancara dengan petani sampel dengan menggunakan daftar pertanyaan (kuesioner) yang terstruktur sesuai dengan kebutuhan data yang mengacu pada topic dan judul penelitian. Data sekunder diperoleh dari berbagai laporan instansi terkait serta literatur lain yang berhubungan dengan penelitian ini. Metode yang digunakan dalam penelitian ini adalah metode survey.Menurut Silalahi, 2010,bahwa survey adalah suatu usaha untuk mendapatkan dan mengumpulkan data dan informasi dari berbagai sumber guna mendukung tujuan penelitian.

Metode penarikan sampel pada penelitian ini dilakukan dengan metode snowboll. Snowbol adalah suatu metode yang digunakan untuk memperoleh sampel pada suatu penelitian jika tidak mengetahui jumlah populasi secara keseluruhan,dengan menggunakan metode snowbol.kita dapat memperoleh sampel dengan cara menemui satu orang petani hidroponik dan kemudian meminta informasi dari petani tersebut siapa saja yang mengusahakan cara budidaya yang sama demikian seterusnya menggelinding seperti bola salju dan berhenti sampai keperluan data dirasakan cukup.Penelitian ini dilaksanakan pada tanggal 15 Maret sampai dengan 15 Juni 2021.

Analisis data merupakan proses yang harusdilakukandengantujuan untuk menyederhanakan data yang diperoleh darilapanganke dalam bentuk yang mudah dibaca dan dipahami kemudian dapat diinterpretasikan, dalam penelitian ini metode yang digunakan adalah metode deskriftif kualitatif. Data yang diperoleh dari lapangan disederhanakan terlebih dahulu dengan cara distribusi,prekuensi dan persentase. Untuk mengetahui gambaran secara umun tentang kondisi sampel,sedangkan untuk melihat persepsi dengan sikap petani hidroponik terhadap sistem pemasaran online sayuran hidroponik dengan menggunakan alat Uji Fisher (Siegel,1997) yang dapat dilihat berikut ini: 
$\frac{P=(a+b) !(c+d) !(a+c) !(b+d) !}{n ! a ! b ! c ! d !}$

Dimana :

$\mathrm{P}=$ Nilai peluang Fisher

$\mathrm{n}=$ Jumlah sampel

$\mathrm{a}, \mathrm{b}, \mathrm{c}, \mathrm{d}=$ komponen matrik dalam tabel kontingensi.

Adapun tabel hubungan antara persepsi dengan sikap terhadap sistem pemasaran online sayuran hidroponik dapatdilihat pada tabel dibawah ini:

Tabel 1.Hubungan Antara persepsi dengan Sikap terhadap sistem pemasaran online sayuranHidroponik:

\begin{tabular}{cccc}
\hline \multirow{2}{*}{ Persepsi } & \multicolumn{3}{c}{ Sikap } \\
\cline { 2 - 4 } & Rendah & Tinggi & $\sum$ \\
\hline Kurang Baik & $\mathrm{a}$ & $\mathrm{b}$ & $\mathrm{a}+\mathrm{b}$ \\
Baik & $\mathrm{c}$ & $\mathrm{d}$ & $\mathrm{c}+\mathrm{d}$ \\
\hline$\sum$ & $\mathrm{a}+\mathrm{c}$ & $\mathrm{b}+\mathrm{d}$ & $\mathrm{n}$ \\
\hline
\end{tabular}

Hipotesis Statistiknya adalah:

Ho $: p=0,05$

Ha $: p \neq 0,05$

Dimana hipotesis operasionalnya :

H0 : Tidak terdapat hubungan antara persepsi dengan sikap petani sayuran hidroponik dengan

Sistem pemasaran online

Ha : Terdapat hubungan antara persepsi dengan sikap petani sayuran hidroponikdengan sistem

Pemasaran online

Selanjutnya untuk mengambil keputusan maka digunakan kaidah pengambilan keputusan sebagai berikut:

$\mathrm{P}<0,05$ Terima $\mathrm{H} 0$ atau Tolak Ha

$\mathrm{P} \geq 0,05$ Tolak $\mathrm{H} 0$ atau Terima Ha

\section{Karakteristik Responden}

\section{HASIL PENELITIAN}

Responden pada penelitian ini adalah petani sayuran pakcoy yang dibudidayakan secara Hidroponik dan merupakan sumber pendapatan ekonomi keluarga. Karakteristik inidiharapkandapat menggambarkan potensi petani seperti kemampuan yang dimiliki petani dalam melaksanakan kegiatan usahataninya. Dari hasil penelitian dapat dijelaskan karakteristik petani yang meliputi,umur,tingkat pendidikan,jumlah anggota keluarga.

\section{a. Umur}

Umur merupakan faktor yang sangat penting dalam proses menghasilkanproduksi.umur dapat mempengaruhi kemampuan petani dalam mengelola usahataninya,baik dalam bekerja,berfikir dan mengambil keputusan hal ini sejalan dengan pendapat Soeharjo dan Patong (1973), yang menjelaskan bahwa secara umum seseorang yang berumur muda serta sehat mempunyai kemampuan fisik yang lebih kuat jika untukbekerja dibandingkan dengan seseorang yang berumur lebih tua, mereka yang berumur muda lebih cepat menerima inovasi baru dan berani menerima risiko dan juga karena mereka masih kurang memiliki pengalaman sehingga petani muda harus dinamis supaya mendapatkan pengalaman baru lebih cepat.

Dari hasil penelitian terhadap 17 orang petani sampel didaerah penelitian,umur petani berkisar antara 29-86 tahun. Untuk lebih jelasnya dapat dilihat pada Tabel 2.

Tabel 2. Distribusi Frekuensi dan persentase petani berdasarkan umur

\begin{tabular}{cccc}
\hline No & Distribusi umur petani (tahun) & Frekuensi (Orang) & Persentase $(\%)$ \\
\hline 1 & $29-39$ & 6 & 35,29 \\
2 & $40-50$ & 7 & 41,18 \\
3 & $51-61$ & 3 & 17,65 \\
4 & $62-72$ & 0 & 0 \\
5 & $78-83$ & 0 & 0 \\
6 & $84-94$ & 1 & 5,88 \\
\hline
\end{tabular}

Sumber: Olahan data primer,2021 
Berdasarkan Tabel 2diatas terlihat bahwa umur petani sampel didaerah penelitian berkisar antara29 -94 tahun,frekuensiumurpetani yang terbesarberada pada kisaran 40-50 tahunatau41,18\% dan prekuensi umur petani yang terkecil berada pada kisaran umur 84-94 tahun yaitu sebanyak 1 orang atau 5,88\% dari jumlah sampel, sedangkan rata-rata umur petani sampel adalah 44 tahun. Kondisi ini menggambarkan bahwa petani sayur pakcoy berada pada umur produktif Menurut Hernanto,(1996) bahwa usia produktif berada pada usia 15-50 tahun.

Dengan demikian ternyata petani sampel masih tergolong muda dan potensial sebagai tenaga kerja dalam usahatani sayur pakcoi,karena pada usia itu petani memiliki kondisi fisik yang kuat untuk bekerja dan dinamis. Demikian juga menurut pendapat Tuwo (2011) angkatan kerja adalah bagian dari penduduk yang berusia 15-50 tahun yang dapat menghasilkan barang dan jasa guna memenuhi kebutuhannya.

\section{b. Tingkat Pendidikan}

Pendidikan yang dilaluiseseorangakan mempengaruhi cara berfikir yang diterapkan dalam kegiatan usahatani pakcoi yaitu kemampuan mengelola usahatani dan menerima teknologi baru. Petani yang pendidikannya rendah pada umumnya akan menutup diri terhadap inovasi baru karena petani tidak dapat mengembangkan potensi agar memiliki kekuatan pengendalian diri, kepribadian dan kecerdasan. Tingkat pendidikan petani diukur berdasarkan tingkat pendidikan formal yang pernah dilaluinya. Salah satu indicator yang dapat mengetahui kualitas sumberdaya manusia adalah tingkat pendidikan penduduk,sejalan dengan pendapat Sumardi,dkk (1997),kemajuan suatu wilayah ditentukan oleh beberapa faktor penting yang mencakup kualitas sumberdaya manusia.

Rendahnya tingkat pendidikan petani bukan berarti bahwa petani kurang terbuka dalam menerima dan menerapkan tehnologi baru yang dianjurkan. Hal ini dapat dilihat bahwa petani mengenal dan menggunakan tehnologi dengan baik dalam membudidayakan tanaman sayuran pakcoi. Untuk mengetahuitingkat pendidikan formal petani sampel dapat dilihat pada Tabel 3 .

Tabel.3. Distribusi Frekuensi Petani Berdasarkan Tingkat Pendidikan

\begin{tabular}{cccc}
\hline No & Distribusi Tingkat Pendidikan Formal & Frekuensi (orang) & Persentase (\%) \\
\hline 1 & Tamat SMP & 2 & 0,34 \\
2 & Tamat SMA & 10 & 1,70 \\
3 & Tamat S1 & 5 & 0,85 \\
\hline & Jumlah & 17 & 100 \\
\hline
\end{tabular}

Sumber: Olahan data primer 2021.

Tabel 3diatas memperlihatkan tingkat pendidikan formal petani sebagian besar tamat SMA 10 orang (1,70 $\%)$ jika dilihat dari tingkat pendidikan ini secara keseluruhan, tingkat pendidikan petani tergolong tinggi, pendidikan yang tinggi mampu meningkatkan kemampuan, wawasan, keahlian serta status dan harapan seseorang dalam menerima perubahan-perubahan dalam perkembangan ilmu pengetahuan dan tehnologi, seperti kemampuan membaca yang sangat berhubungan dengan perkembangan kemajuan kegiatan usaha yang dijalankan. Soeharja dan Patong (1993) menyatakan bahwa semakin tinggi tingakat pendidikan seseorang maka kemampuan petani untuk meningkatkan pengelolaan usahatani akan lebih baik terutama dari segi teknologi baru,pemahaman budidaya dan pemasaran.

\section{c. Jumlah anggota keluarga}

Jumlah anggota keluarga akan mempengaruhi rasa tanggung jawab petanisebagaikepalakeluarga terhadap kebutuhan keluarga.Semakin banyak anggota keluarag semakin besar pula dorongan bagi petani untuk memenuhi kebutuhan keluarga.Selain itu jumlah anggota keluarga yang besar akan mempengaruhi pengelolaan usahataninya karena apabila pendapatan tidak mencukupi maka pengelolaan usaha juga akan terhambat karena akan lebih mengutamakan kebutuhan keluarga

Adapun jumlah anggota keluarga petani dapat dilihat pada Tabel 4 berikut ini:

Tabel 4. Distribusi Frekuensi Petani Berdasarkan Jumlah Anggota Keluarga.

\begin{tabular}{cccc}
\hline No & Distribusi Jumlah Anggota Keluarga (orang) & Frekuensi (orang) & Persentase (\%) \\
\hline 1 & 0 & 1 & 5,88 \\
2 & 1 & 1 & 5,88 \\
3 & 2 & 0 & 0 \\
4 & 3 & 5 & 29,41 \\
5 & 4 & 7 & 41,18 \\
6 & 5 & 3 & 17,65 \\
\hline & Jumlah & 17 & 100 \\
\hline
\end{tabular}

Sumber: Olahan data primer 2021 
Dari Tabel 4 diatas terlihat bahwa petani yang mempunyai persentase terbesar pada kelompok jumlah anggota keluarga 4 sebanyak 7 orang $(41,18 \%)$ dari jumlah sampel dengan rata-rata jumlah anggota keluarga 3,5 (4) orang.Hal ini berarti bahwa petani mempunyai anggota keluarga yang cukup besar, besarnya anggota keluarga dapat dimanfaatkan sebagai sember tenaga kerja dalam keluarga sehingga dapat meringankan biaya upah tenaga kerja, selain itu tenaga kerja yang berasal dari dalam keluarga berbeda dengan yang bersumber dari luar keluarga karena tenaga keluarga akan lebih memiliki rasa tanggung jawab yang lebih besar terhadap usaha yang dijalankan.

\section{d. Persepsi petani terhadap pasar sayur online}

Persepsi petani terhadap pasar online sebagian besar kurang baik,untuk lebih jelasnya distribusi frekuensi dan persentase petani terhadap pasar online dapat dilihat pada Tabel 5 berikut ini.

Tabel 5. Distribusi Frekuensi Petani Berdasarkan Persepsi Terhadap Pasar SayurOnline

\begin{tabular}{|c|c|c|c|}
\hline No & KategoriPersepsi & Frekuensi (orang) & Persentase (\%) \\
\hline 1 & Kurang Baik & 12 & 70,58 \\
\hline 2 & Baik & 5 & 29,40 \\
\hline & & 17 & 100 \\
\hline
\end{tabular}

Sumber: Data primer diolah,tahun 2021

Dari Tabel 5 diatas terlihat bahwa dari 17 orang petani sampel ternyata 12 orang atau (70,58\%) mempunyai persepsi kurang baikterhadap pasar online.Persepsi petani yang kurangbaik terhadap pasar online didasarkan pada beberapa alasan antara lain,karena petani harusmemiliki modal untuk menyiapkan seperangkat alat yang diperlukan untuk memberikan informasi kepada konsumen selain itu petani sayur hidroponik dalam proses produksinya memerlukan biaya yang besar sehingga petani menjual produk dengan harga yang jauh lebih tinggi dari harga pasar tradisional dan ini menyebabkan konsumen lebih sedikit hal ini sesuai dengan daya beli masyarakat jambi yang masih rendah. Daya beli masyarakat yang masih rendah inilah yang menyebabkan bertani sayur dengan cara hidroponik belum begitu banyak diusahakan oleh petani di Kota Jambi.

\section{Perilaku petani terhadap pasar online}

Perilaku petani dalam penelitian ini adalah keikut sertaan petani dalam melakukan pemasaran sayur secara online, sesuai dengan konsepsi pengukuran terbagi atas dua kategori yaitu rendah dan tinggi, dikatakan rendah apabila petani sedikit sekali atau tidak pernah menggunakan aplikasi sistem pemasaran online, sedangkan tinggi apabila petani pernah bahkan hanya memakai sistem pemasaran online.

Berdasarkan hasil dari penelitian menunjukan bahwa sikap petani dalam melakukan pemasaran online menunjukan kategori sebagian besar rendah. Untuk lebih jelasnya mengenai perilaku petani terhadap pasar online dapat dilihat pada Tabel 6 berikut ini :

Tabel 6. Distribusi Frekuensi Petani Berdasarkan Sikap Terhadap Pemasaran Online

\begin{tabular}{|c|c|c|c|}
\hline No & Kategori Sikap & Frekuensi (orang) & Persentase $(\%)$ \\
\hline 1 & Rendah & 14 & 82,35 \\
\hline 2 & Tinggi & 3 & 17,65 \\
\hline \multicolumn{2}{|c|}{ Jumlah } & 17 & 100 \\
\hline
\end{tabular}

Sumber: Data primer diolah,tahun 2021

Berdasarkan Tabel 6 diatas terlihat bahwa 14 orang atau 82,35\% petani memiliki sikap rendah dalam pemasaran sayuran secara online petani yang memiliki sikap tinggi sebanyak 3 orang atau $17,65 \%$. Sikap petani yang rendah ini karena petani hanya sebatas mendengar dan mengetahui bahwa memasarkan produk bisa melalui online namun petani belum memahami tentang penggunaan sistem aplikasi pemasaran online dengan baik namun sebagian petani bersikap tinggi terhadap aplikasi pemasaran online ini karena petani berharap ada tenaga ahli untuk mensosialisasikan cara pemasaran online ini. Selain itu petani berkeinginan adanya program yang dibuat oleh pemerintah untuk meningkatkan ilmu pengetahuan petani tentang aplikasi pemasaran produk secara online

\section{Hubungan Persepsi dengan Sikap Petani Sayur Terhadap Pasar Online Di Kota Jambi}

Persepsi terhadap pasar online merupakan salah satu bentuk penilaian atau pandangan petani dalam melakukan pemasaran sayur yang dapat memberikan dampak bagi petani terhadap keadaan sosial ekonominya. Persepsi petani terhadap pasar online diduga terdapat hubungan yang erat dengan sikap petani dalam memasarkan sayurnya. Dengan adanya persepsi baik terhadap suatu objek maka akan diiringi dengan sikap dalam melakukan tindakan yang tinggi terhadap pasar online. Namun sebaliknya jika persepsi yang kurang baik maka akan diikuti dengan sikap dalam 
melakukan tindakan yang rendah terhadap pasar online. Untuk lebih jelasnya hasil penelitian tentang hubungan persepsi dengan sikap petani sayur pakcoy terhadap pasar online di Kota Jambi dapat dilihat pada Tabel 7 berikut ini.

$\underline{\text { Tabel 7. Hubungan Persepsi dengan Sikap Petani Terhadap Pasar Online. }}$

\begin{tabular}{clcccccc}
\hline \multirow{2}{*}{ No } & \multirow{2}{*}{ Persepsi } & \multicolumn{3}{c}{ Sikap } & \multicolumn{2}{c}{ Tinggi } & \multirow{2}{*}{ Jumlah } \\
\cline { 3 - 6 } & & \multicolumn{2}{c}{ Rendah } & Orang & Persentase (\%) & Orang & Persentase $(\%)$ \\
No & Kategori & Orang & Persentase (\%) & 0 & 12 & 70,58 \\
1 & Kurang Baik & 12 & 70,58 & 0 & 17,64 & 5 & 29,40 \\
2 & Baik & 2 & 11,76 & 3 & 17,64 & 17 & 100 \\
& Jumlah & 14 & 82,34 & 3 & 0
\end{tabular}

Sumber: Data primer diolah,tahun 2021

Hasil dari tabulasi silang pada Tabel 7 menunjukkan bahwa dari 17 orang petani sayur hidroponik yang berpersepsi kurang baik dan diikuti dengan sikap rendahsebanyak 12 orang atau 70,58\%,sedangkan yang mempunyai persepsi baik dan diikuti dengan sikap rendah sebanyak 2 orang atau 11,76\%. Yang mempunyai persepsi baik dan diikuti dengan sikap tinggi sebanyak 3 orang atau 17,64\% Kondisi ini memperlihatkan bahwa petani sayur mengetahui cara memasarkan produk bisa melalui online namun dalam mempergunakan aplikasi sistem pemasaran online petani harus mempelajarinya dengan baik karena petanitau dengan memasarkan produk melalui cara online bisa memperoleh pendapatan yang lebih baik dari pada harus memasarkan ke pasar biasa, disamping itu tak perlu lagi harus mengantar sayur kepasar biasa dengan risiko yang cukup besar yaitu harus mencari pelanggan untuk membeli dagangannya dan harus mengeluarkan biaya untuk sampai kepasar tersebut juga harus menunggu sampai sayurannya habis terjual sedangkan kondisi sayuran tersebut semakin siang semakin layu dan tentunya nilai jual akan lebih rendah. Oleh karena itu petani sangat berharap ada bantuan dari pihak pemerintah melalui penyuluh mengadakan pelatihan khusus untuk mempelajari cara memasarkan produk melalui aplikasi online.

Dari hasilperhitungan Uji Fisher diperoleh :

$$
P=\frac{(a+b) !(c+d) !(a+c) !(b+d) !}{n ! \cdot a ! \cdot b ! \cdot c ! . d !}
$$

$\mathrm{p}=\frac{(12+0) !(2+3) !(12+2) !(0+3) !}{17 ! .12 ! .0 ! \cdot 2 ! \cdot 3 !}=$

$\mathrm{P}=\underline{(12) !(5) !(14) !(3) !}=0,015$

$17 ! .12 ! .0 ! .2 ! 3 !$

Nilai peluang Fisher $=0,015(\mathrm{p}<0,05)$ yang berarti terima Ho dan tolah Ha atau tidak terdapat hubungan antara persepsi dengan sikap petani sayur hidroponik terhadap sistem pemasaran online di Kota Jambi.

\section{KESIMPULAN}

Berdasarkan dari hasil pembahasan sebelumnya maka dapat disimpulkan bahwa :

1. Persepsi petani sayur hidroponik terhadap sistem pemasaran online yang ada di Kota Jambi Kurang baik sebanyak 12 orang atau 70,58\% dan didukung dengan sikap yang rendah

2. Sikap petani sayur hidroponik terhadap sistem pemasaran online yang ada di Kota Jambi rendah dan didukung dengan persepsi yang baik sebanyak 2 orang atau $11,76 \%$

3. Tidak terdapat hubungan persepsi dengan sikap petani sayur hidroponik terhadap sistem pemasaran online di Kota Jambi. 


\section{DAFTAR PUSTAKA}

Anindita R.2004, Baladian N, 2016. Pemasaran Produk Pertanian.Penerbit Andi Yokyakarta.

Anindita R,2004.Pemasaran Hasil Pertanian.Papyrus. Surabaya.

Dinas Perindustrian dan Perdagangan (Disperindag) Provinsi Jambi,2020

Dinas Pertanian Tanaman Pangan Hortikultura dan Peternakan Provinsi Jambi,2018. Luas Lahan dan Produktivitas Tanaman Hortikultura.

Hernanto 1996, Ilmu Usahatani. Penebar Swadaya.Jakarta

Kotler. P2007, Dasar-dasar Pemasaran. Jakarta Pt Indek

Patong S 1994, Ekonomi Pertanian Indonesia. Angkasa. Bandung

Siegel, Sidney 1997. Statistik Non Parametrik.Gramedia Pustaka Utama.Jakarta

Singarimbun. 1982. Metode Penelitian Survay LP3ES.Jakarta

Silalahi U.2010, MetodePenelitian Sosial. Refika Aditama. Bandung

Tuwo, M. Akib. 2011, Ilmuusahatani Teori dan Aplikasi Menuju Sukses.Unhalu Press. Kendari 